\title{
GEOCHEMICAL CHARACTERIZATION OF NATURAL GAS MANIFESTATIONS IN GREECE
}

\author{
D’Alessandro W. ${ }^{1}$, Brusca L. ${ }^{1}$, Martelli M. ${ }^{1}$, Rizzo A. ${ }^{1}$ and Kyriakopoulos K. ${ }^{2}$ \\ ${ }^{1}$ Istituto Nazionale di Geofisica e Vulcanologia, sezione di Palermo, via U. La Malfa 153, 90146 Palermo, \\ Italy,w.dalessandro@pa.ingv.it \\ ${ }^{2}$ National and Kapodistrian University of Athens, Dept. of Geology and Geoenvironment, \\ Panepistimioupolis, 15784 Ano Ilissia, Greece, ckiriako@geol.uoa.gr
}

\begin{abstract}
The Greek region is characterized by intense geodynamic activity with widespread volcanic, geothermal and seismic activity. Its complex geology is reflected in the large variety of chemical and isotopic composition of its gas manifestations.

Basing on their chemical composition the gases can be subdivided in three groups, respectively $\mathrm{CO}_{2}$, $\mathrm{CH}_{4}$ or $\mathrm{N}_{2}$-dominated. On oxygen-free basis these three gases make up more than $97 \%$ of the total composition. The only exceptions are fumarolic gases of Nisyros that contain substantial amounts of $\mathrm{H}_{2} \mathrm{~S}$ (up to more than 20\%) and one sample of Milos that contains $15 \%$ of $\mathrm{H}_{2} . \mathrm{CO}_{2}$-dominated gases with clear mantle contribution in their He isotopic composition $\left(R / R_{a}\right.$ corrected for air contamination ranging from 0.5 to 5.7) are found along the subduction-related south Aegean active volcanic arc and on the Greek mainland close to recent (upper Miocene to Pleistocene) volcanic centers. These areas are generally characterized by active or recent extensive tectonic activity and high geothermal gradients. On the contrary, gases sampled in the more external nappes of the Hellenide orogen have generally a $\mathrm{CH}_{4}$ - or $\mathrm{N}_{2}$-rich compositions and helium isotope composition with a dominant crustal contribution $\left(R / R_{a}\right.$ corr $\left.<0.2\right)$.

The chemical and isotopic characteristics of the emitted gas display therefore a clear relationship with the different geodynamic sectors of the region. Gas geochemistry of the area contributes to a better definition of the crust-mantle setting of the Hellenic region.
\end{abstract}

Key words: natural gas manifestations, gas chemistry, He- and C-isotope composition.

\section{Introduction}

The Hellenic territory has a very complex geodynamic setting deriving from a long and complicated geological history. Many of the geologic features of Greece are still argument of strong debate and Zeilinga de Boer (1989) defined its geodynamic situation as "The Greek enigma". The Hellenic territory is also the site of intense seismic activity (Burton et al., 2004) and enhanced geothermal gradient (Fytikas and Kolios, 1979). This together with the presence of an active volcanic arc favours the existence of many cold and thermal gas manifestations.

Until now only scarce data on chemical and isotopic composition of these gas manifestations have been published. Furthermore these data are either limited to single volcanic/geothermal systems 


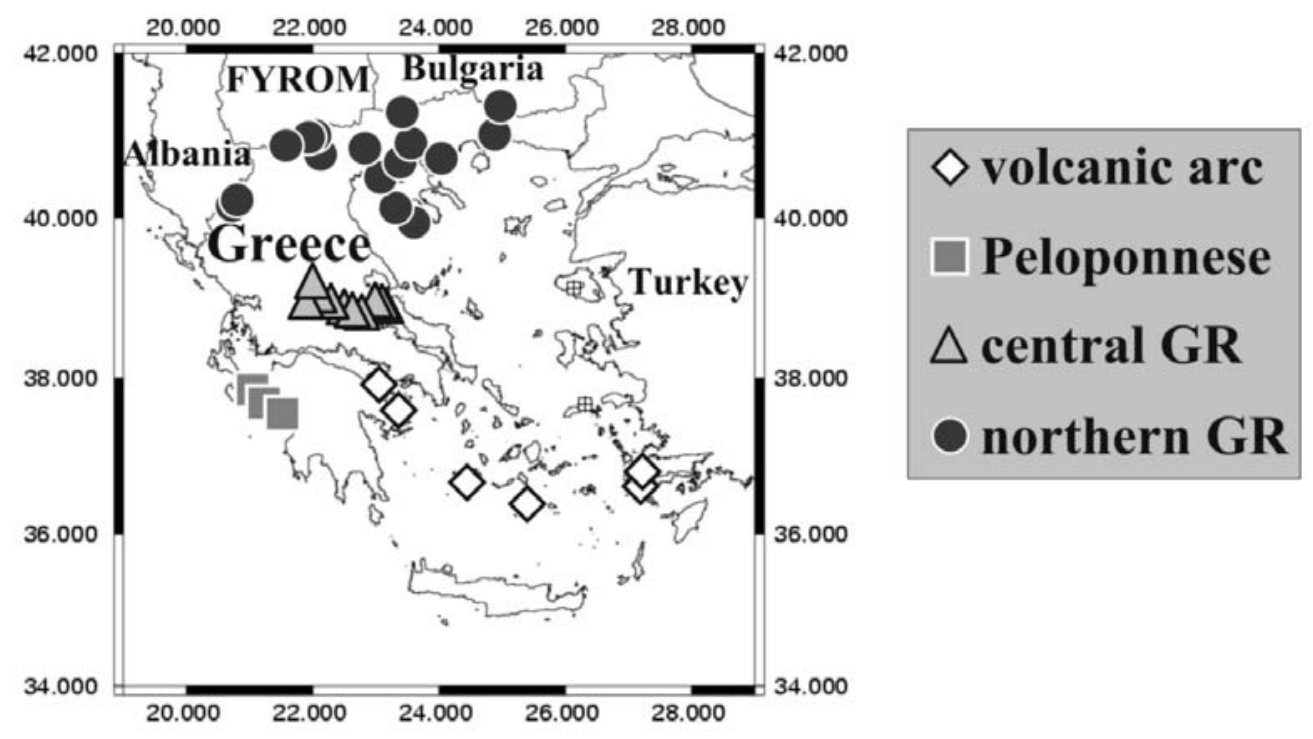

Fig. 1: Geographic distribution of the sampled gas manifestations.

(Marini and Fiebig, 2005; D'Alessandro et al., 2008) or if considering geographically wider areas they refer only to their chemical (Minissale et al., 1989; 1997) or to their noble gas isotopic (Shimizu et al., 2005) composition. In the present study both the chemical and the isotopic composition (C, $\mathrm{He}$ ) of 52 samples collected along the whole Hellenic territory has been analysed in an attempt to reveal possible relationships with the geodynamic situation.

\section{Study area and methods}

\subsection{Geological setting}

The Aegean region is a concentrate of the main geodynamic processes that shaped the Mediterranean region: oceanic and continental subduction, mountain building, high-pressure and low-temperature metamorphism, backarc extension, post-orogenic collapse, metamorphic core complexes, gneiss domes are the ingredients of a complex evolution that started at the end of the Cretaceous with the closure of the Tethyan ocean along the Vardar suture zone (Jolivet and Brun, 2008).

The Greek and west Anatolian region was affected by a Tertiary and Quaternary volcanism with an orogenic signature. The oldest products are of upper Eocene-Oligocene age and are exposed in limited volumes in the northern part of Greece. The volcanic activity reached a climax in the Lower Miocene and was exhausted by the Middle Miocene (Yilmaz et al., 2001).

The Paleogene Hellenide orogeny of Greece and its eastward continuation into western Turkey resulted from collision of the Apulian microcontinental fragment in the Eocene to Oligocene with the Pelagonian, Rhodope, and Serbo-Macedonian fragments, which had previously accreted to the southern margin of Eurasia in the Cretaceous. Subsequent extension in the Aegean was rapid, likely due 
to subduction rollback over residual oceanic crust of the African plate, whereas Anatolia had been bounded by African continental crust south of Cyprus since the Early Miocene. This regional extension and the thermal effects of asthenospheric upwelling, related to changes in the geometry of subducting slabs, have been interpreted as causing magma genesis principally within the lithospheric mantle (Pe-Piper and Piper, 2002).

At the south Aegean Volcanic Arc the volcanic activity started during the Upper Pliocene (Fytikas et al., 1986) and is still active today mainly in the form of solfatara activity. The calc-alkaline volcanic activity of Southern Aegean region developed in various volcanic centers from Sousaki to Nisyros through Methana-Poros, Milos and Santorini. The volcanic products are dominated by lava domes and lava flows with associated minor pyroclastic breccias and felsic ignibritic covers (Mitropoulos et al., 1987). The final activity of this orogenic cycle is characterized by the presence of K-rich shoshonites and latites with ultrapotassic character.

\subsection{Sampling and analytical methods}

A total of 52 samples were collected along the whole Hellenic territory (Fig. 1). Free gas samples were taken from natural gas manifestations like fumarolic discharges, soil gases, mofettes, gas bubbling in cold or thermal waters and also from wells drilled either for groundwater or carbon dioxide abstraction or for geothermal exploration. Water for dissolved gas analyses were collected in glass vials sealed underwater.

Fumarolic gas discharges and soil gases were collected at a depth of $50 \mathrm{~cm}$ through steel or nylon tubes connected to a syringe while bubbling gases were collected through inverted funnels. Samples were then stored into glass flasks equipped with vacuum stopcocks.

Gas concentrations were measured at INGV in Palermo using the GC Perkin Elmer Clarus 500 equipped with Carboxen 1000 columns, HWD and FID detectors with methanizer. The gas samples were injected through an automated injection valve with a $1000 \mu \mathrm{L}$ loop. Calibration was made with certified gas mixtures. Analytical precision ( $1 \sigma)$ was always better than $\pm 5 \%$. The detection limits were about $1 \mathrm{ppm}$ vol. for $\mathrm{CH}_{4}, 2 \mathrm{ppm}$ vol. for $\mathrm{H}_{2}, 6 \mathrm{ppm}$ vol. for $\mathrm{He}, 20 \mathrm{ppm}$ vol. for $\mathrm{CO}_{2}, 200 \mathrm{ppm}$ vol. for $\mathrm{O}_{2}$ and $500 \mathrm{ppm}$ vol. for $\mathrm{N}_{2}$. He concentrations less than $6 \mathrm{ppm}$ were determined during $\mathrm{He}$ isotopic analysis with a detection limit of about $0.1 \mathrm{ppm}$. Dissolved gases in water samples were extracted using the head-space equilibration method according to Capasso and Inguaggiato (1998).

Analyses of carbon isotopes of $\mathrm{CO}_{2}$ were carried out by using a Finnigan Delta plus mass spectrometer. Values of carbon isotope of $\mathrm{CO}_{2}$ are expressed in $\delta \%$ vs. V-PBD, accuracy being $0.1 \delta \%$. The method proposed by Capasso et al. (2005) was used for determination of the $\delta^{13} \mathrm{C}$ of total dissolved inorganic carbon (TDIC). The theoretical equilibrium composition of a free $\mathrm{CO}_{2}$ gas phase was calculated considering the fraction of all dissolved carbon species $\left(\mathrm{H}_{2} \mathrm{CO}_{3}, \mathrm{HCO}_{3}{ }^{-}\right.$and $\left.\mathrm{CO}_{3}{ }^{2-}\right)$ and the relative fractionation factors.

The He-isotope ratio in the gas samples was analysed directly from the sample bottles after purification in the high-vacuum inlet line of the mass spectrometer. The isotope composition of dissolved He was analysed by headspace equilibration, following the method proposed by Inguaggiato and Rizzo (2004). He isotopes were measured with a modified double-collector mass spectrometer (VG 5400-TFT). ${ }^{3} \mathrm{He} /{ }^{4} \mathrm{He}$ ratios, determined against an air standard, are referred here to the atmospheric ratio $\left(\mathrm{R}_{\mathrm{a}}=1.386 \times 10^{-6}\right)$ as $\mathrm{R} / \mathrm{R}_{\mathrm{a}}$. Measured values were corrected for the atmospheric contamination of the sample on the basis of its ${ }^{4} \mathrm{He} /{ }^{20} \mathrm{Ne}$ ratio (Sano and Wakita, 1985) determined with a quadrupole mass spectrometer (QMS, VG Quartz). 


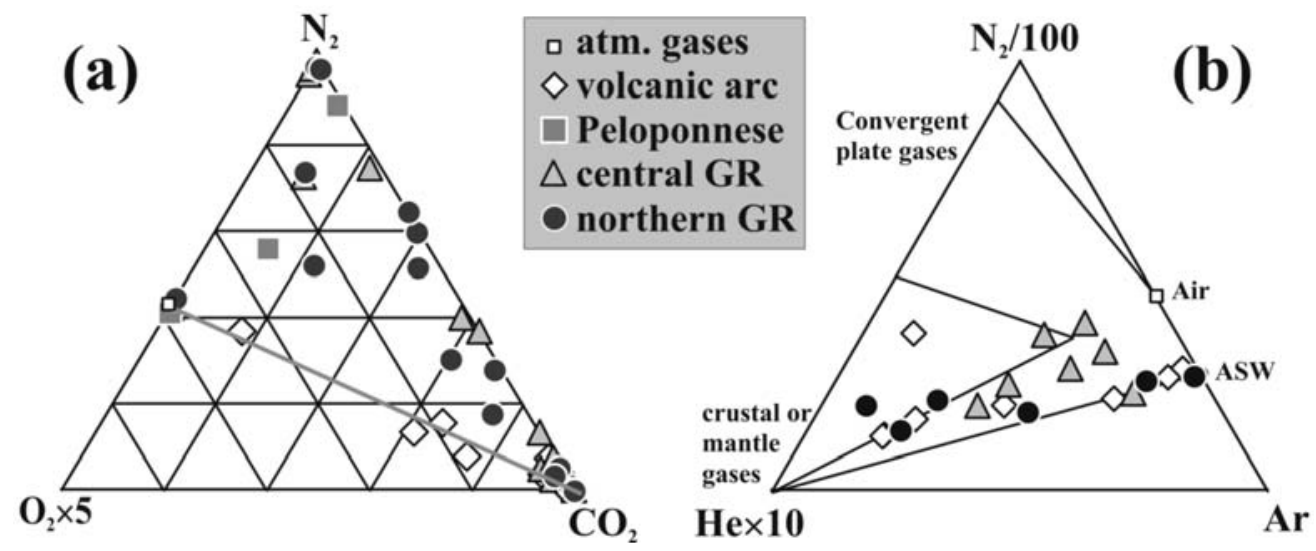

Fig. 2: a) $\mathrm{O}_{2}-\mathrm{N}_{2}-\mathrm{CO}_{2}$ triangular plot and b) $\mathrm{He}-\mathrm{N}_{2}-\mathrm{Ar}$ triangular plot. Symbols as in Fig. 1 refer to the geographical distribution of the sampling sites.

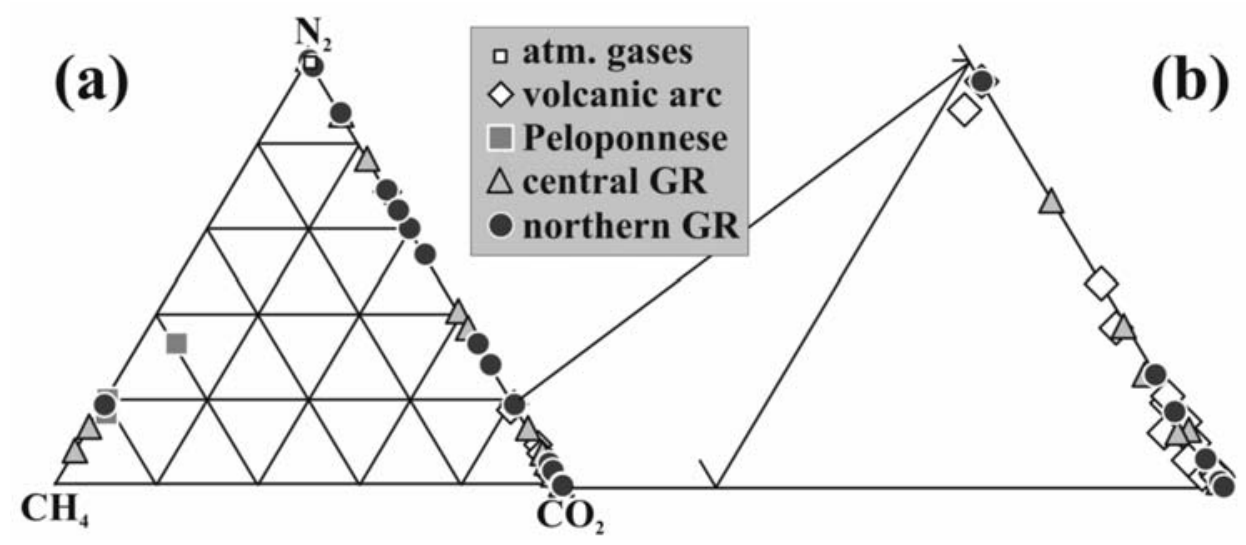

Fig. 3: a) $\mathrm{CH}_{4}-\mathrm{N}_{2}-\mathrm{CO}_{2}$ triangular plot. b) enlargement of the $\mathrm{CO}_{2}$ vertex. Symbols as in Fig. 1 refer to the geographical distribution of the sampling sites.

\section{Results and discussion}

\subsection{Chemical composition of the gases}

The results of the chemical analyses are listed in Table 1. They are reported as dry gases excluding water vapour, which is significant only in the fumarolic gas samples of Nisyros. The gas samples display a very large variability in chemical composition. Helium ranges from 0.4 up to $2940 \mathrm{ppm}$ and shows a fair positive correlation with $\mathrm{N}_{2}$. Only 21 samples have detectable $\mathrm{H}_{2}(>2 \mathrm{ppm})$ concentrations ranging from 5 up to $149000 \mathrm{ppm}$. Oxygen concentrations range from below the detection limit ( $<200 \mathrm{ppm}-11$ samples) up to $193000 \mathrm{ppm}$. The concentrations of $\mathrm{N}_{2}, \mathrm{CH}_{4}$ and $\mathrm{CO}_{2}$ range from 600 to 978000 , from less than 1 to 915000 and from 27 to $993000 \mathrm{ppm}$ respectively. The last three species represent always the main gas component and all the samples can be subdivided in $\mathrm{N}_{2}{ }^{-}, \mathrm{CH}_{4}{ }^{-}$and $\mathrm{CO}_{2}{ }^{-}$ dominated gases. On oxygen-free basis these three gases represent generally more than $97 \%$ of the total composition. The only exceptions are fumarolic gases of Nisyros that contain substantial amounts 


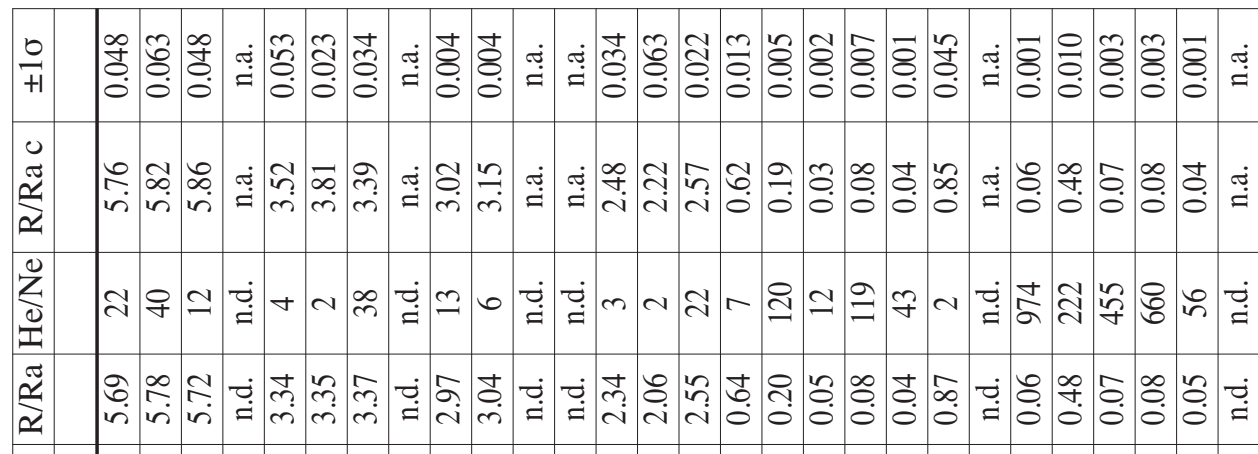

ชิ

Uِ $\frac{2}{20}$

ن

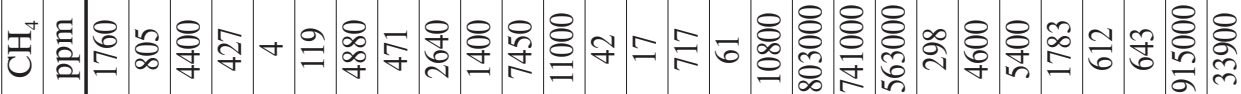

"

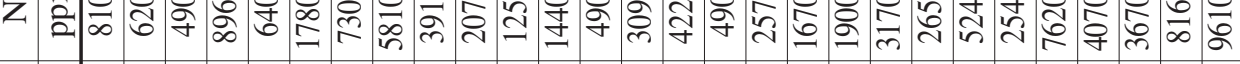
০

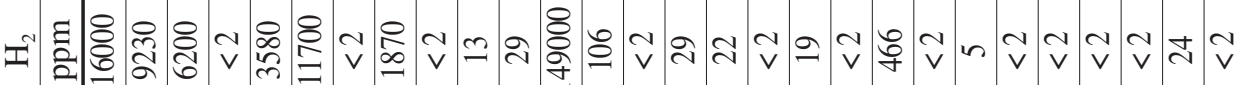

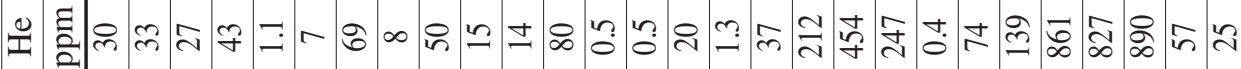

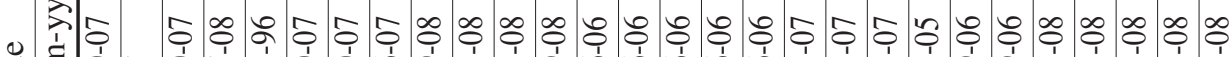

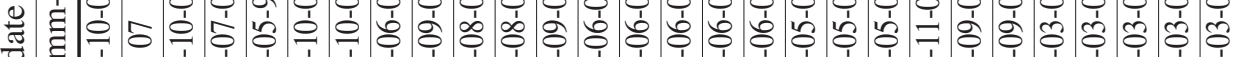
¿

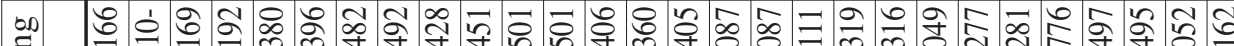
o

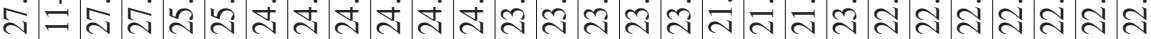
車 六

ก

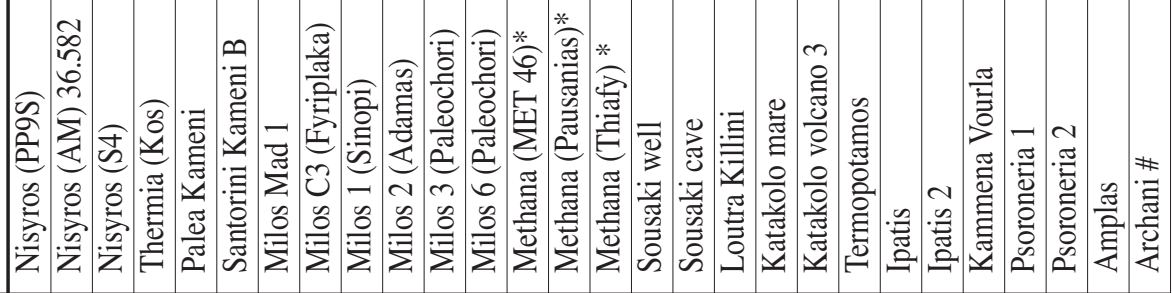




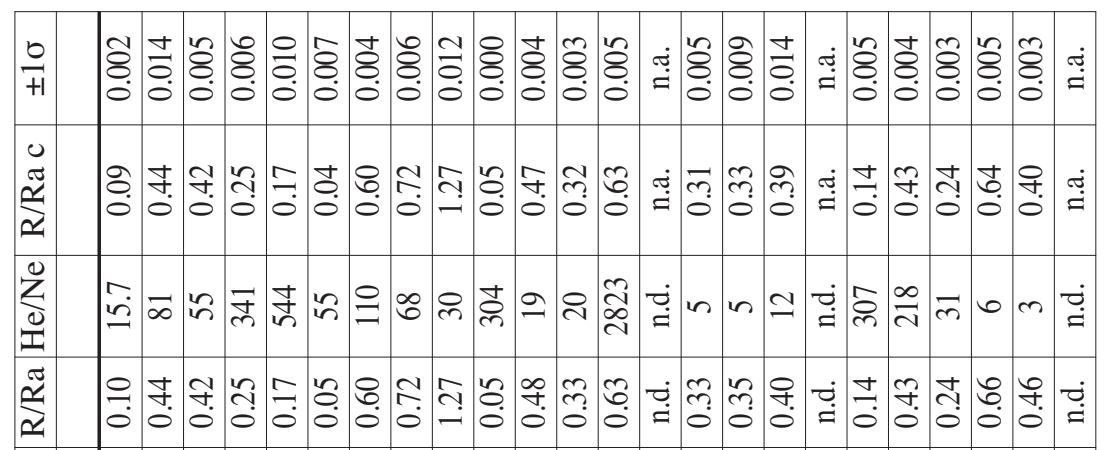

$\sum_{0}^{0} 0$

눙

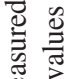

छ

을

일

중

엉

.్ㅇㅇํ

กิต

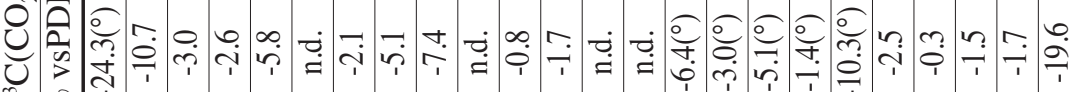
-

ن

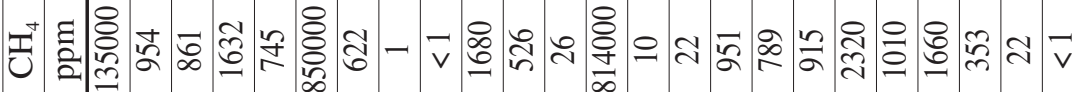

Z

o

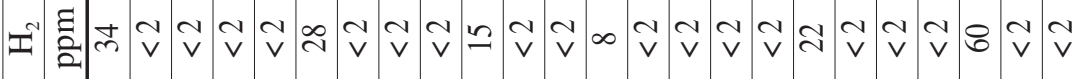

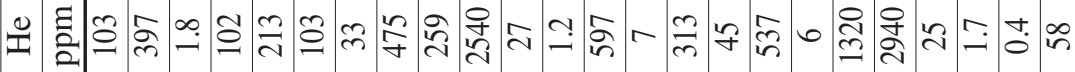

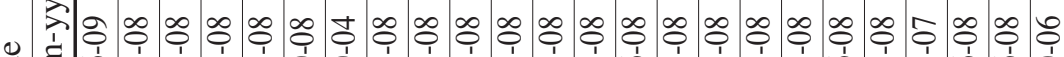

苛

吾

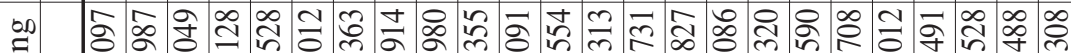

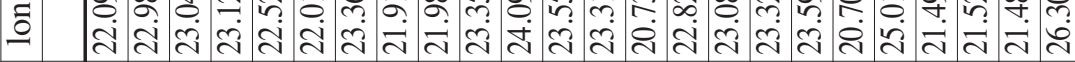

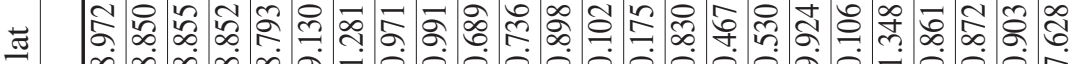

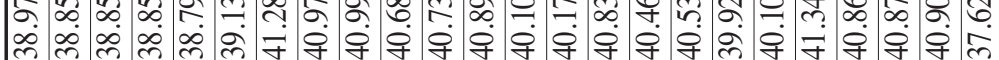

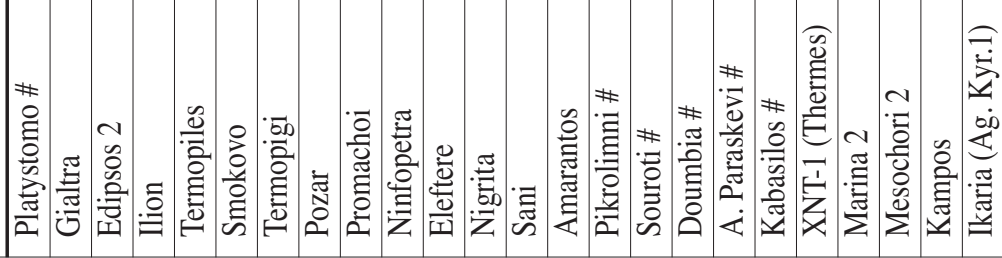

范

䒕 :

훙

प्र

ڤึ

\#

$\circ \stackrel{0}{0}$

언

है ते

屯

을 윻

$\cong$ 들

ن गे

额.

슬

의 웜

귱

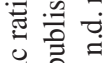

放至

के

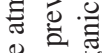
\&

$\circ \stackrel{0}{\circ}$.

겅

恣

Ðீ

䨌

雨

욜

웜

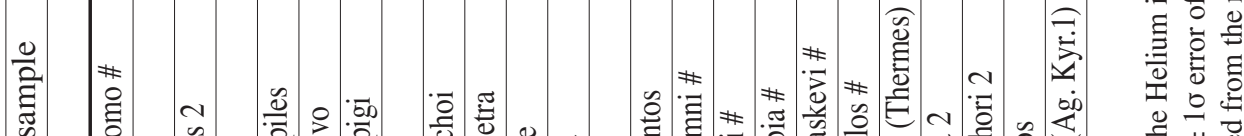
$\stackrel{0}{ \pm}+1$ $\therefore \dot{0} \frac{\vec{t}}{\exists}$ 告荥 


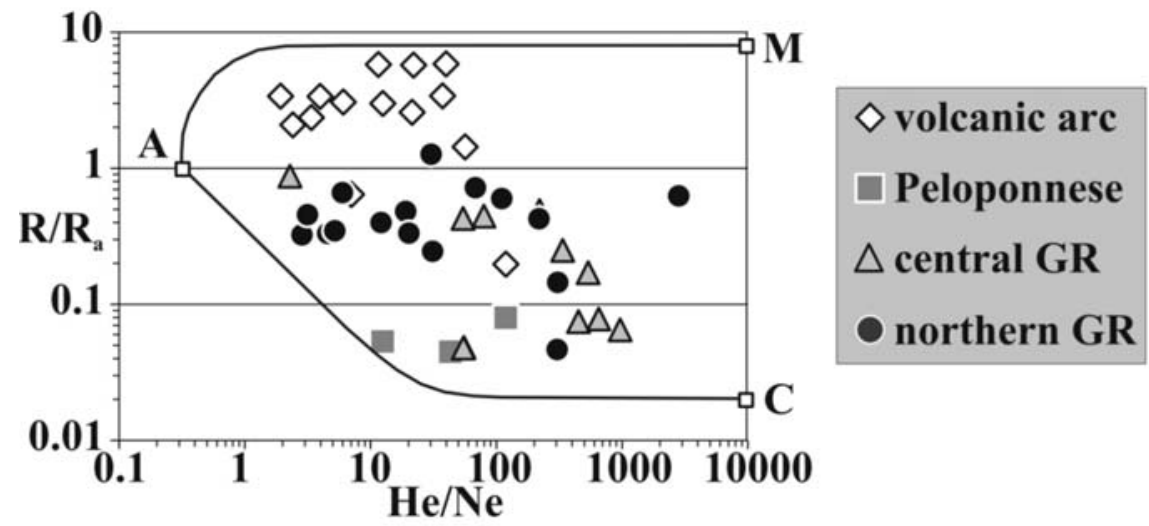

Fig. 4: $\mathrm{R} / \mathrm{R}_{\mathrm{a}}$ vs. He/Ne plot of the natural gas manifestations of Greece. A, $\mathrm{M}$ and $\mathrm{C}$ represent three possible end-members: atmospheric air, MORB-like mantle and crust. The mixing lines between $\mathrm{A}$ and $\mathrm{M}$ and between $\mathrm{A}$ and $\mathrm{C}$ are also plotted.

of $\mathrm{H}_{2} \mathrm{~S}$ (up to more than 20\%) and one sample of Milos that contains $15 \%$ of $\mathrm{H}_{2}$.

The $\mathrm{O}_{2}-\mathrm{N}_{2}-\mathrm{CO}_{2}$ triangular plot (Fig. 2a) reveals that only few samples plot close to the point representing atmospheric air excluding important contaminations for most samples. Furthermore most samples display $\mathrm{N}_{2} / \mathrm{O}_{2}$ ratios much higher than the atmospheric one indicating that the atmospheric component deriving from meteoric recharge has probably been modified by redox reactions in the subsoil. Great contributions of $\mathrm{N}_{2}$ deriving from slab-sediments can be ruled out by the $\mathrm{N}_{2} / \mathrm{Ar}$ ratios, which are generally close to the atmospheric, or the air-saturated water ratios (Fig. 2b). Furthermore most of the samples show a strong contribution of helium deriving either from a crustal or a mantle source.

The $\mathrm{CH}_{4}-\mathrm{N}_{2}-\mathrm{CO}_{2}$ triangular plot (Fig. 3a) shows that only 6 samples display a $\mathrm{CH}_{4}$-dominated composition comprising all 3 samples collected in the Peloponnese, two samples of central Greece and one of northern Greece. $\mathrm{N}_{2}$ - and $\mathrm{CO}_{2}$-dominated gases display on the same plot a mixing line (Fig. $3 a)$. To the latter group, the most abundant (32 samples), belong all the samples collected along the active south Aegean volcanic arc (Fig. 3b) except one sample of Milos (Fyriplaka) contaminated with atmospheric air (Fig. 2a). Most of the $\mathrm{N}_{2}$-dominated gases were collected in northern Greece (Fig. 3a).

\subsection{Isotopic composition of the gases}

The results of the isotopic analyses are listed in table 1 . He isotopic values, expressed as ${ }^{3} \mathrm{He} /{ }^{4} \mathrm{He}$ ratio normalised to the atmospheric one $\left(\mathrm{R}_{\mathrm{a}}=1.386 \times 10^{-6}\right)$, range from 0.03 to $5.78 \mathrm{R} / \mathrm{R}_{\mathrm{a}}$. Measured values corrected for the atmospheric contamination of the sample on the basis of its ${ }^{4} \mathrm{He} /{ }^{20} \mathrm{Ne}$ ratio (Sano and Wakita, 1985) display a similar range $\left(\mathrm{R} / \mathrm{R}_{\mathrm{a}}\right.$ corr $\left.0.03-5.86\right)$. Such a wide range is indicative of different sources for the helium in the studied gases.

In Figure 4 the measured $\mathrm{R} / \mathrm{R}_{\mathrm{a}}$ values are plotted against the ${ }^{4} \mathrm{He} /{ }^{20} \mathrm{Ne}$ ratio together with the characteristic composition of three possible sources, the atmosphere (A), a MORB-like mantle (M) and the crust $(\mathrm{C})$. The plot excludes strong atmospheric contaminations because only few samples display low ${ }^{4} \mathrm{He} /{ }^{20} \mathrm{Ne}$ ratios close to the characteristic end-member of atmospheric air. Samples col- 


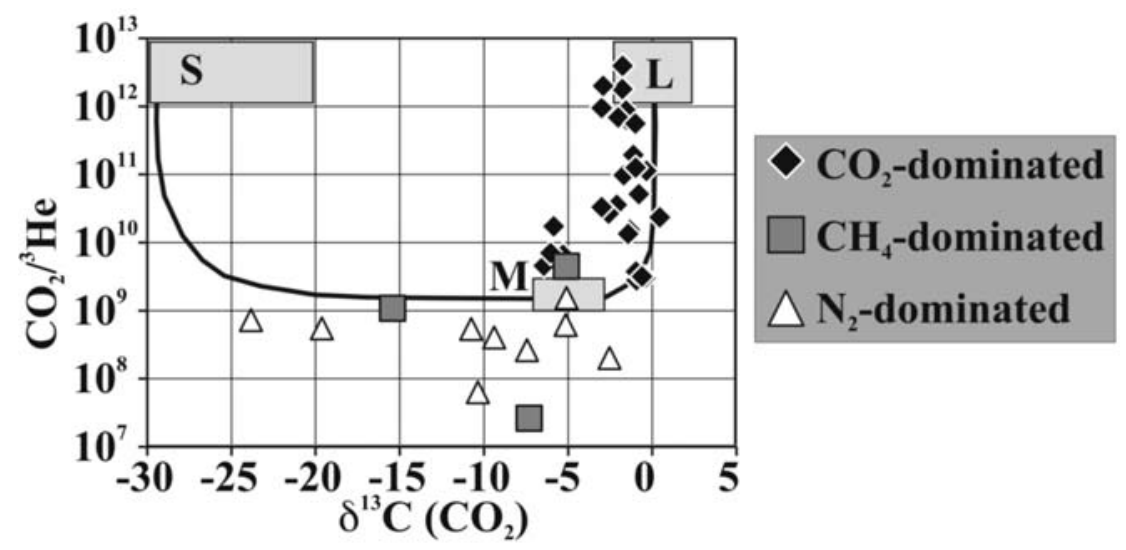

Fig. 5: $\mathrm{CO}_{2}{ }^{3} \mathrm{He}$ vs. $\delta^{13} \mathrm{C}\left(\mathrm{CO}_{2}\right)$ plot of the natural gas manifestations of Greece. The endmember compositions for sediments (S), MORB-like mantle (M) and limestones (L) are $\delta^{13} \mathrm{C}\left(\mathrm{CO}_{2}\right)=-30 \%,-5 \%$ and $0 \%$; and $\mathrm{CO}_{2}{ }^{\beta} \mathrm{He}=1^{\prime} 10^{13}, 2^{\prime} 10^{9}$ and $1^{\prime} 10^{13}$, respectively (Sano and Marty, 1995).

lected along the volcanic arc display the highest mantle contribution with all but the samples collected at Sousaki having values above $1 \mathrm{R} / \mathrm{R}_{\mathrm{a}}$. A few samples, among which are all those collected in the Peloponnese, display a prevailing crustal imprint $\left(R / R_{a}<0.2\right)$. Most of the samples display intermediate helium isotopic composition $\left(R / R_{a}\right.$ between 0.2 and 1$)$ evidencing contributions of both deep sources (mantle and crust).

The carbon isotopic composition of $\mathrm{CO}_{2}$ in the free gas samples ranges from -19.6 to $+0.5 \delta^{13} \mathrm{C} \%$ (vs. V-PDB). For the dissolved gas samples the theoretical isotopic composition of gaseous $\mathrm{CO}_{2}$ in equilibrium with the liquid phase has been calculated from the following measured parameters, temperature, $\delta^{13} \mathrm{C}$ of the total dissolved inorganic carbon, dissolved $\mathrm{CO}_{2}$ concentration and alkalinity, considering all fractionation factors between gas and all dissolved carbon species (Zhang et al., 1995). The obtained values range from -24.3 to $-1.4 \delta^{13} \mathrm{C} \%$. All $\mathrm{CO}_{2}$-dominated gases display a narrower range spanning from -6.4 to $+0.5 \delta^{13} \mathrm{C} \%$ and in this group the samples collected along the volcanic arc have still narrower range $\left(-2.0-+0.5 \delta^{13} \mathrm{C} \%\right.$ ).

Considering the $\delta^{13} \mathrm{C}\left(\mathrm{CO}_{2}\right)$ values and the $\mathrm{CO}_{2}{ }^{3} \mathrm{He}$ ratios (Fig. 5), samples collected along the volcanic arc plot on the mixing line between the mantle and the limestones end-members. This pattern further excludes important contributions from organic sediments to the fluids deriving from the descending slab. A small contribution from organic sediments can be detected in the $\mathrm{CO}_{2}$-dominated gases of mainland Greece deriving probably from crustal sources. On the contrary $\mathrm{CH}_{4}{ }^{-}$and $\mathrm{N}_{2}-$ dominated gases display sometimes a strong organic contribution and low $\mathrm{CO}_{2} /{ }^{3} \mathrm{He}$ ratios probably due to $\mathrm{CO}_{2}$-depleting processes (carbonate precipitation, $\mathrm{CO}_{2}$ reduction, etc.).

\subsection{Geographical distribution}

Measured $R / R_{a}$ values of the Greek gas manifestations display an increasing trend going from north to south and from west to east (Fig. 6). A similar trend has been previously also evidenced by Shimizu et al. (2005) for the south Aegean volcanic arc. Based on the ${ }^{87} \mathrm{Sr} /{ }^{86} \mathrm{Sr}$ ratios of the least evolved rocks, they attributed this pattern to increasing crustal contamination of ascending magma. 


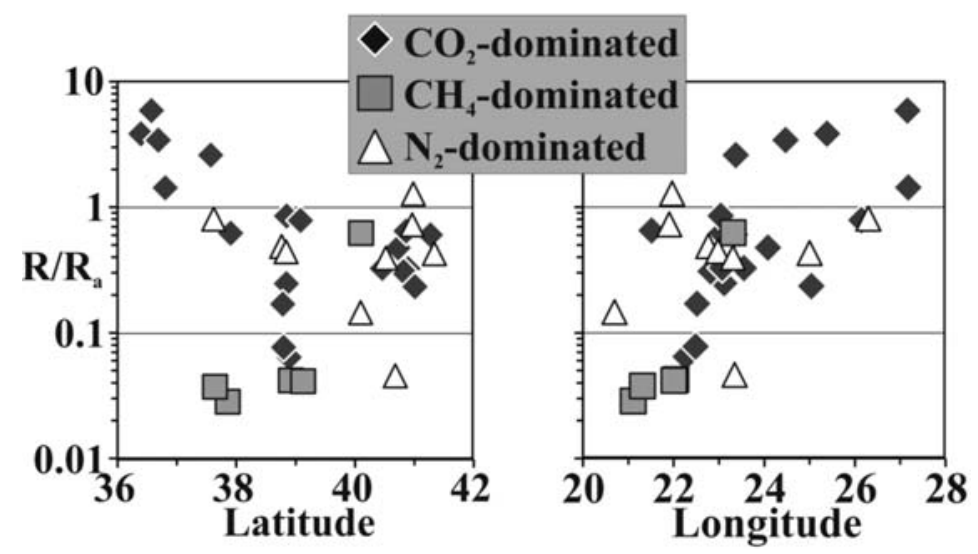

Fig. 6: Variation of measured $R / R_{a}$ values of the Greek gas manifestations vs. latitude (left) and longitude (right) of the sampling site.

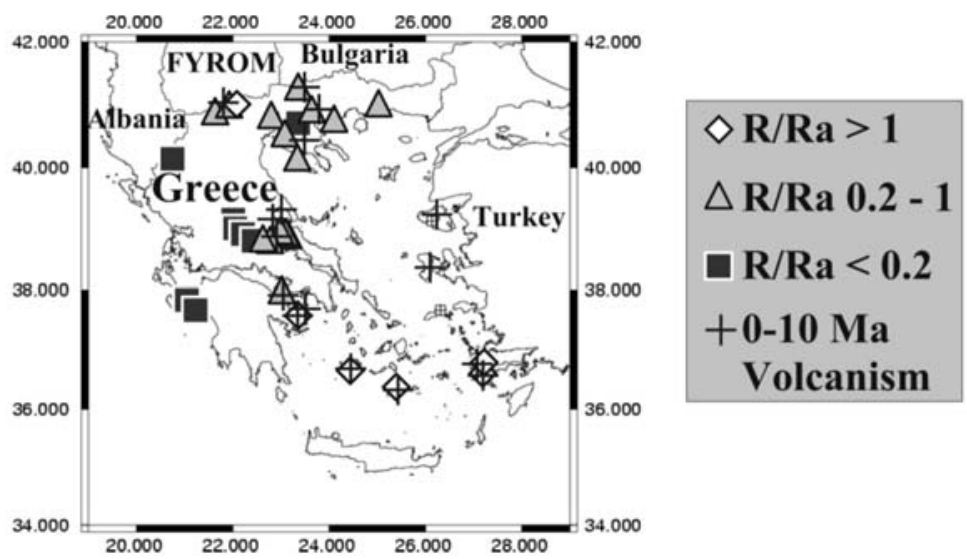

Fig. 7: Relationships between He isotopic compositions measured in the natural gases and the recent volcanic manifestations of the Hellenic territory.

Crustal contamination along the volcanic arc could be due to several processes. For example, PePiper and Piper (2005) subdivided the arc in an older part comprising Methana and Milos and a more recent part comprising Santorini and Nisyros. Volcanism is considered to be slowly decreasing in the western sector, and the ascent of new magma from the mantle, being currently much lower than in the eastern part, supports a lower ${ }^{3} \mathrm{He}$ flux. A further significant difference between the eastern and western parts of the arc is in the type of volcanism. Santorini and Nisyros (in the east) are both characterized by central stratovolcanoes with large calderas and frequent eruptive activity during historical time (Pe-Piper and Piper, 2002). This volcanic environment facilitates the easy and rapid ascent of mantle fluids, and a corresponding lower probability of crustal contamination. In contrast, Methana and Milos (in the west) exhibit numerous monogenic centres accompanied by lower eruptive rates (Fytikas et al., 1986), which is compatible with a higher crustal contamination in the emitted fluids. 
Gases with a clear crustal imprint in their He isotopic composition $\left(R / R_{a}<0.2\right)$ are found almost exclusively in the western part of Greece. In this area where the more external nappes of the Hellenide orogen crop out, the thickness of the crust reaches the highest values of the Hellenic region $(>40 \mathrm{~km})$.

Gases with intermediate He isotopic composition $\left(R / R_{a} 0.2-1\right)$ have been collected across the most internal terrains of the Hellenide orogen. In this area crustal thinning, due to extensive tectonics, favoured the recent $(<10 \mathrm{Ma}$ ) volcanic activity and either direct or magma-mediated mantle fluids ascent. This area is also the site of enhanced geothermal gradient (Fytikas and Kolios, 1979). Noteworthy almost all sites where gas samples with intermediate He isotopic composition (Fig. 7) have been collected fall close to recent volcanic centers and/or within the zones of highest geothermal gradient.

\section{Conclusions}

The 52 gas manifestations sampled along the whole Hellenic territory can be subdivided, on the basis of their chemical composition, in $\mathrm{CH}_{4}-\mathrm{N}_{2}$ and $\mathrm{CO}_{2}$-dominated. The former two groups, almost all collected in the western part of the country, display also very low $\mathrm{R} / \mathrm{R}_{\mathrm{a}}$ values $(<0.2)$ highlighting their crustal origin. This region is characterised by a high crustal thickness (up to $>40 \mathrm{~km}$ ) and absence of recent $(<10 \mathrm{Ma})$ volcanic manifestations. On the contrary samples collected in the eastern part of Greece, where instead the crust is thinner $(20-30 \mathrm{~km})$ and recent volcanic manifestations are widespread, the gases have generally $\mathrm{CO}_{2}$-dominated composition and intermediate $\mathrm{R} / \mathrm{R}_{\mathrm{a}}$ values $(0.2-1)$ evidencing a significant contribution from a mantle source. Finally, a strong mantle contribution was found in the samples collected along the south Aegean active volcanic arc, which all display a $\mathrm{CO}_{2}$-dominated composition and high $\mathrm{R} / \mathrm{R}_{\mathrm{a}}$ values $(1-5.8) . \mathrm{CO}_{2}$ carbon isotopic composition and the $\mathrm{CO}_{2}{ }^{\beta} \mathrm{He}$ ratio of the latter gases evidence a mixing between a mantle and a limestone source excluding any contribution from sedimentary material. This is also confirmed by the measured $\mathrm{N}_{2} /$ Ar ratios, which are all close either to the atmospheric or to the air-saturated water ratio. A small contribution from sedimentary material, probably of crustal origin, can be highlighted in the $\mathrm{CO}_{2}$-dominated gases of continental Greece.

\section{Acknowledgments}

We kindly acknowledge all the Greek colleagues that helped us either in the field or with precious informations about the sampling sites. Among them we remember E. Dotsika, Prof. N. Lambrakis, S. Karakatsanis, K. Katsanou, N. Kolios, M. Margaritopoulos, G. Michas, G. Papadakis.

\section{References}

Burton, P.W., Xu, Y., Qin, C., Tselentis, G., Sokos, E., 2004. A catalogue of seismicity in Greece and the adjacent areas for the twentieth century. Tectonophysics, 390, 117-127.

Capasso, G. and Inguaggiato, S., 1998. A simple method for the determination of dissolved gases in natural waters. An application to thermal waters from Vulcano Island. Applied Geochemistry $13,631-642$.

Capasso, G., Favara, R., Grassa, F., Inguaggiato, S., Longo, M., 2005. On-line technique for preparation and measuring stable carbon isotope of total dissolved inorganic carbon in water samples $\left(\delta^{13} \mathrm{C}_{\mathrm{TDIC}}\right)$. Annals Geophysics 48, 159-166.

D’Alessandro W., Brusca L., Kyriakopoulos K., Michas G., Papadakis G., 2008. Methana, the westernmost active volcanic system of the south Aegean arc (Greece): insight from fluids geochemistry. Journal of Volcanology and Geothermal Research 178, 818-828. 
Fytikas, M. and Kolios, N., 1979. Preliminary heat flow map of Greece. In: Cermak, V., Rybach, L., (eds) Terrestrial heat flow in Europe. Springer-Verlag, pp 197-205.

Fytikas, M., Innocenti, P., Manetti, R., Mazzuoli, R., Peccerillo, A. Villari, L., 1984. Tertiary to Quaternary evolution of volcanism in the Aegean region. In: J.E. Dixon and A.H.F Robertson (Editors), The Geological evolution of the Eastern Mediterranean. Geol. Soc. London, Spec. Publ., 17:687-699.

Fytikas, M., Innocenti, F., Kolios, N., Manetti, P., Mazzuoli, R., 1986. The Plio-Quaternary volcanism of the Saronikos area (western part of the active Aegean volcanic arc). Annales Geologique des Pays Helleniques 33, 23-45.

Inguaggiato, S. and Rizzo, A., 2004. Dissolved helium isotope ratios in groundwaters: a new technique based on gas-water re-equilibration and its application to Stromboli volcanic system. Applied Geochemistry 19, 665-673.

Jolivet, L. and Brun, J.P., 2008. Cenozoic geodynamic evolution of the Aegean. International Journal of Earth Sciences doi: 10.1007/s00531-008-0366-4.

Matini, L. and Fiebig, J., 2005. Fluid geochemistry of the magmatic-hydrothermal system of Nisyros (Greece). In: The geology, geochemistry and evolution of Nisyros volcano (Greece). Implications for the volcanic hazards (Hunziker, J.C. and Marini, L. eds.), Memoires de Geologie, 44, 121-163.

Minissale, A., Duchi, V., Kolios, N., Totaro, G., 1989. Geochemical characteristics of Greek thermal springs. Journal of Volcanology and Geothermal Research 39, 1-16.

Minissale, A., Duchi, V., Kolios, N., Nocenti, M., Verrucchi, C., 1997. Chemical patterns of thermal aquifers in the volcanic islands of the Aegean arc, Greece. Geothermics, 26, 501-518.

Mitropoulos, P., Tarney, J., Saunders D., Marsh N., 1987. Petrogenesis of cenozoic volcanic rocks from the Aegean Island Arc. Journ. Volcanology and Geothermal Research, 32, 177-193.

Pe-Piper, G. and Piper, D.J.W., 2002. The Igneous Rocks of Greece. Stuttgart, Borntraeger, 645 p.

Pe-Piper, G., Piper, D.J.W., 2005. The south Aegean active volcanic arc: relationships between magmatism and tectonics. In: The south Aegean active volcanic arc (Fytikas, M., Vougioukalakis, G.E. eds.) - Developments in Volcanology 7, 113-133.

Sano, Y. and Marty, B., 1995. Origin of carbon in fumarolic gas from island arcs. Chemical Geology 119, 265-274.

Sano, Y. and Wakita, H., 1985. Geographical distribution of ${ }^{3} \mathrm{He} /{ }^{4} \mathrm{He}$ in Japan: implications for arc tectonics and incipient magmatism. Journal of Geophysical Research 90, 8729-8741.

Shimizu, A., Sumino, H., Nagao, K., Notsu, K., Mitropoulos, P., 2005. Variation in noble gas isotopic composition of gas samples from the Aegean arc, Greece. Journal of Volcanology and Geothermal Research 140, 321-339.

Zeilinga de Boer, J., 1989. The Greek enigma: is development of the Aegean orogene dominated by forces related to subduction or obduction? Marine Geology 87, 31-54.

Zhang, J., Quay, P.D., Wilbur, D.O., 1995. Carbon isotope fractionation during gas-water exchange and dissolution of $\mathrm{CO}_{2}$. Geochimica et Cosmochimica Acta 59, 107-114. 